\title{
Homenagem ao Prof. Dr. Jaderson COSta da COSTA
}

\section{Prêmio “The Ambassador for Epilepsy Awards"}

Durante a cerimônia de abertura do $26^{\text {th }}$ International Epilepsy Congress (ILAE) e International Bureau of Epilepsy (IBE), o Prof. Dr. Jaderson Costa da Costa foi um dos homenageados com a premiação.

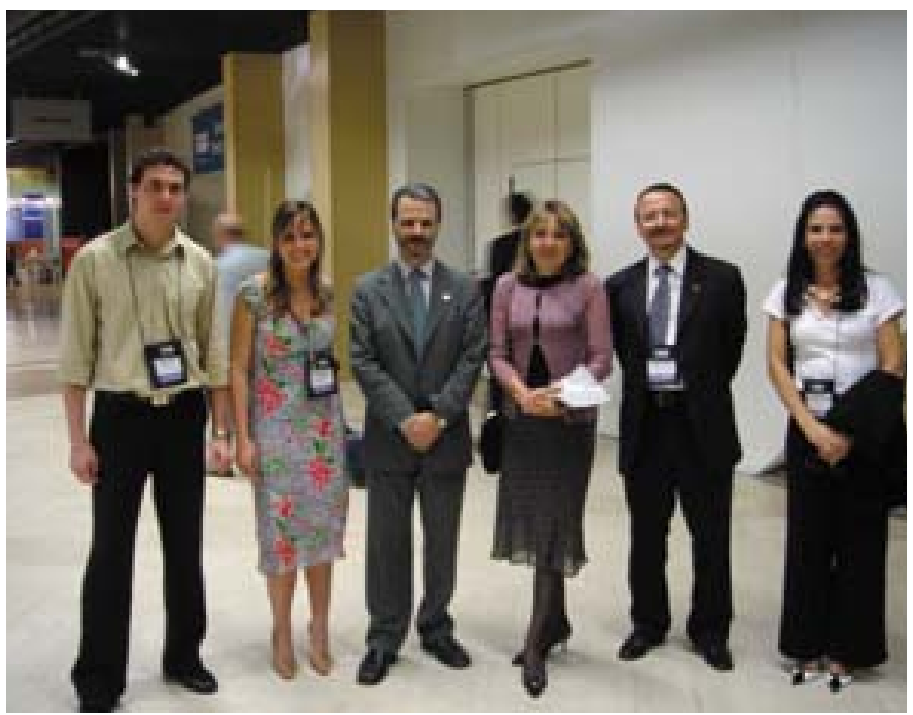

Prof. Dr. Jaderson Costa da Costa, com membros da atual Diretoria da LBE: Profa. Dra. Magda L. Nunes e Profa. Mirna Portuguez, com o

Prof. Dr. Jorge Audy, Vice-Reitor de Pesquisa e Pós-Graduação da PUCRS, e os doutorandos Bianca M. Barea e Ricardo Wainberg, alunos premiados com um dos trabalhos apresentados durante o Congresso da ILAE.
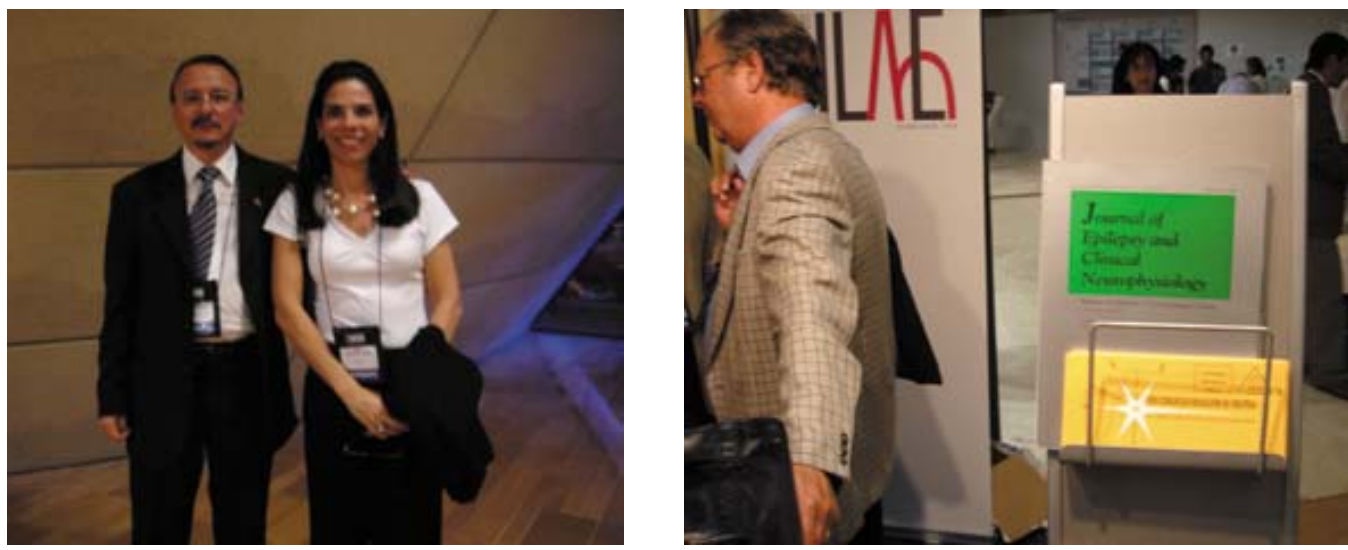